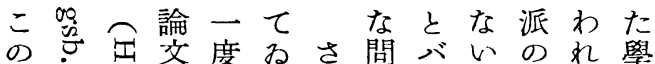

の・攵度わさ問バいのれ學近

論のもをびたて題、の研に說年

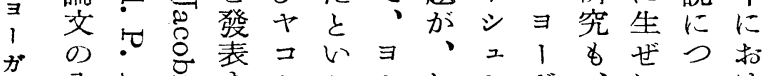

- 公? 占す

ス 刊

れ引古及授风派风立原一わ度

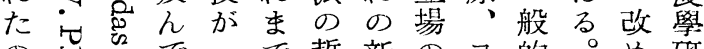

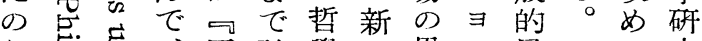

ち悲点、原弘學し異 1 風いて究

に出密そ始く思心同方潮は檢の

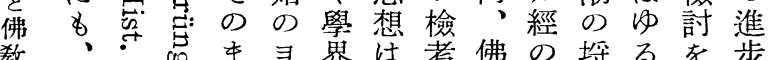

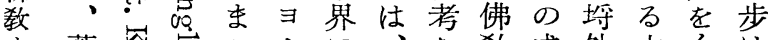

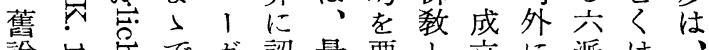

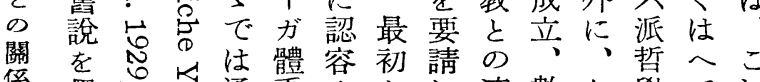

係墨。落通系さ加し連數打學てれ

金守ち苟用にれらて關論かのみま

す 岂望しつて數ねな說る一るで

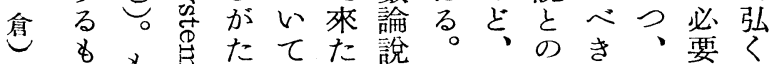

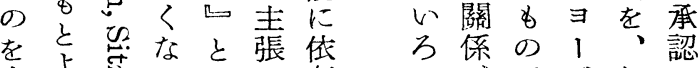

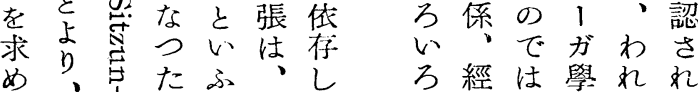

1

ガ

ス.

I

r

ラ

のをたのか存ると展論度る結え 二懷りさ論へのたの教示文をと果な 三い異て文しヨと始授しは明しにい にて論、にて、い原のて、加てすで つるがこ於みがふに研る該にも年は いるあのてる・に於究る博示、なな

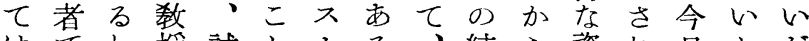

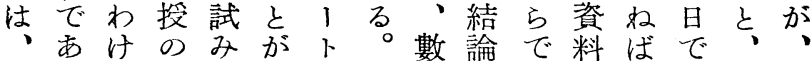
私るで結てでラそ論はあるなは考そ に。は論るき皮しと、る、ら、へ 納しなそるるびて關二。周な豫らは 得かくのわとヨ、係言到いめ狆

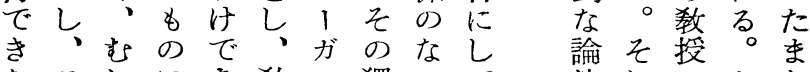
なこしにあ教・獨いてて法れのかた いのろつる授バ特獨いすををを研りま 子結々W。自、の自へ必究に呚 の論のてらシ體の将つ要を從授

一がを煈、采形、てを批來の 含8 眼私 のヤ而寻新方制の業 またに自復か、上、新るし主績 竹敬 てし敬、を、見兟を見

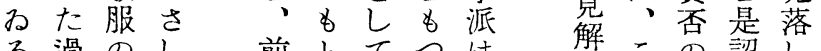
る過のしし 前と前市 記に現て<smiles>[AlH2]</smiles>

倉 ๑) 成 I. 之 
な最れはなっ授者いがはすで要突融、が印無そ 心初、、らな隔自は、、しる、視怘合ガ・度條の でか是一なるた身六經はか立スし它し・シ人件一

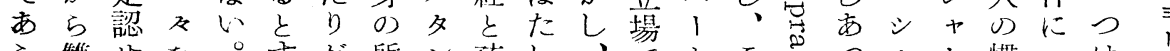

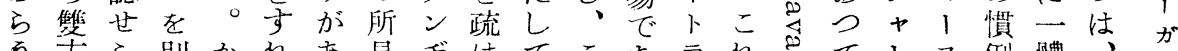

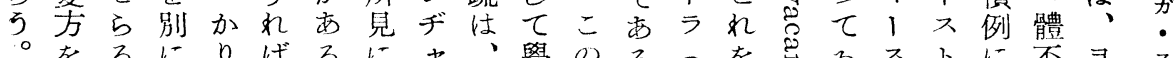
をるに同べ調に

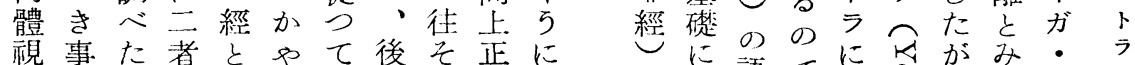
し 柄結が疏 5 \& 者れ正に てで果全は、、はぞい偑

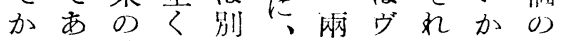
る。綜京偑作者中别 ど著 る。合じの作の、人弓述 のかと立對者間サのかかを はやし場象制にで作、無 与てにと制は市交私條 獨な、古し作、る傳は件

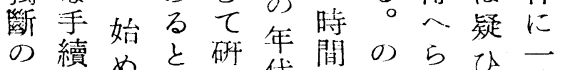
そをなとし究代的み犯を體

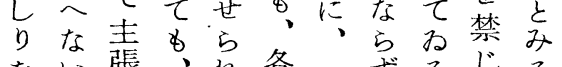

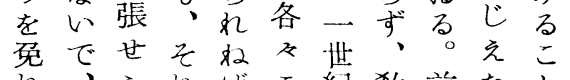
れ、らればこ紀教前なと 視ま重哥に全の

そ持はのスを數どーるからたるか經解必部はの の込、基 1 媒論ま回。らうたにに明ず研、立こ 機ん全本下介につださ兩。ちれグ好しし究别場の

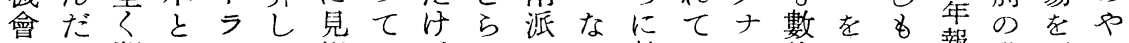
をの問しでな慣わ、にがぜ數わへ論行同報發明う 與は題てはくれるこ謗共な論る性とつ—第表かな

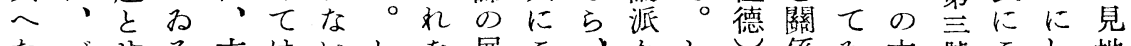
たバせる古はいしを展こ、かし係る立號こし地 に すシれ實數二のの示にをののしがあのに照をらら ざょなは諭十で、のつ波場借、とるは據、ゆと、 なナい認の五あそ分い取合用グか思、る今ゔ息私 以以○め諦りこ節てつをと想䟽と、ら身は と後數がうの、にこ字た考解說、がでい結ねでま

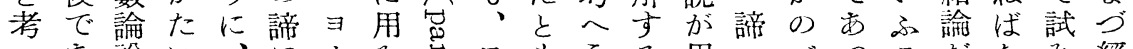
へあ說い、に

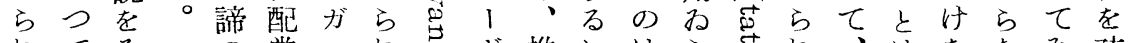

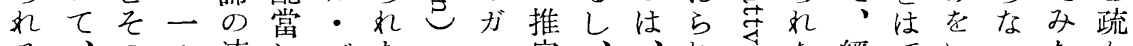

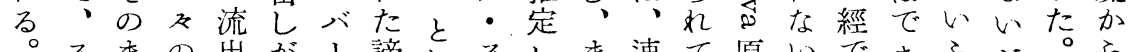
スまの出が１諦し 大しま速て原いできふがっら二 1〉諦やたシのていた切 卜ヨの還いュ名、トるでない經東の離 ラ 1 定滅。ヤ稱あ

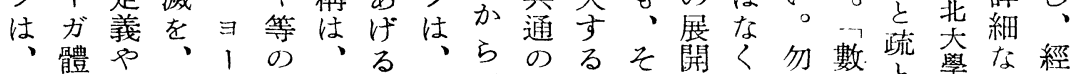
た采機體が末古に單で源でれが、論論文學報自 だに能系・疏典とにあ泉あをし明、の學告體 
今けま究りでれてし慢が意接なに度言で界

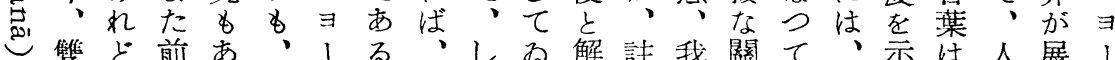
、雙ど前あ、1る、しる解註我閣て、示は人展、 ヨ行方名記りさ方。佛ばるせ釋見係る全し、間開ガ

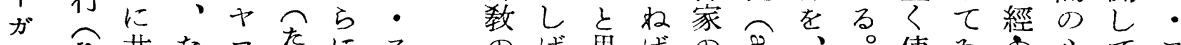

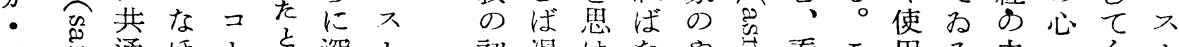

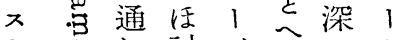

1 し討ビばいト

卜则た究敎は。ラ

ラ 特を授木すを

○、殊 加の村で佛

威業の方論泰に敎

立の術ぶ要监、の

俤志語き博こ關

教力を部、士の係

と站离こ仺關は

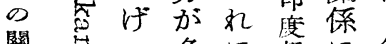

關豆て多に晢に從

係要みく重學つ來

金空る殘要佛い考

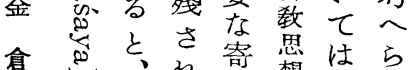
、行焉想は如

種㥜て密學て 秏氣わな附者わ

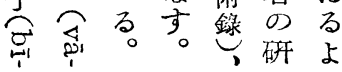

初混はなや等看こ用る中こく

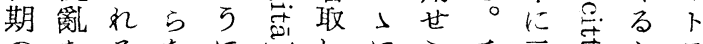
のをるなにししにらす三きをラ

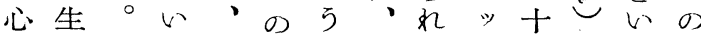
し詰こそ如るわなタ一のふ中 或て翠とれきでれいの回探や心 はわ家はは言あわの語市求万問 識るのな數葉られには用にな題

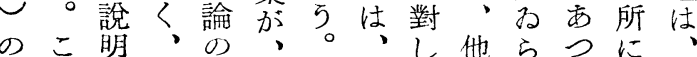

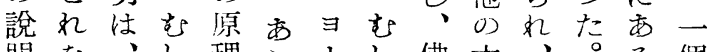
明を、し理らاし佛六、。る個 に機ころとはガろ教派術心のの 、能れチしれ文当で哲語へで原 よをらッてなく、はは學とチは理 く示の夕の施ガ重のしッなか

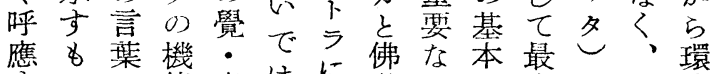
等のに能意はに较用的大と方境 るとつを・な覺の語聖の心くの の军い示我い覺密に典頻方ま世

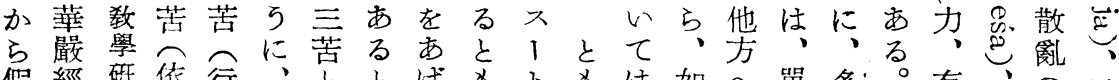

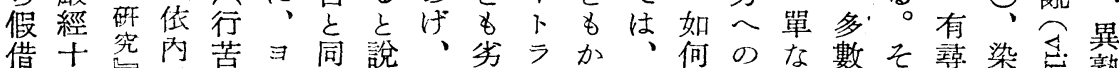

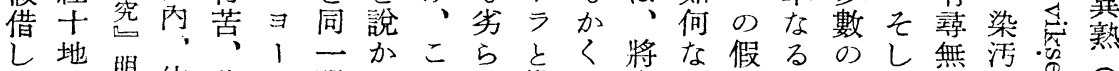

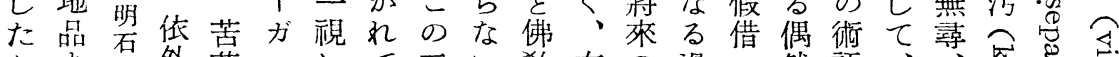

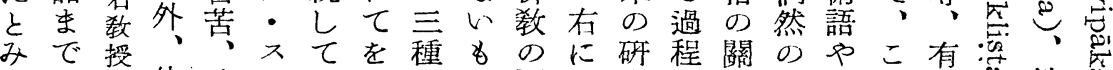

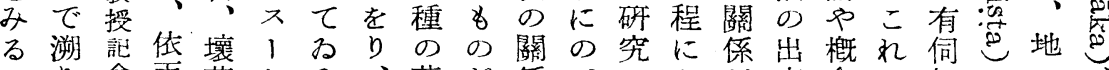
心゙念天苦上る、苦が係べよが來念ら無等令

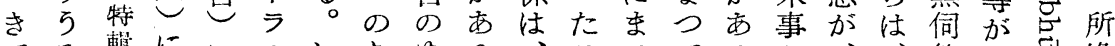

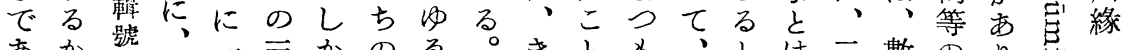

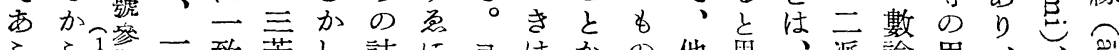

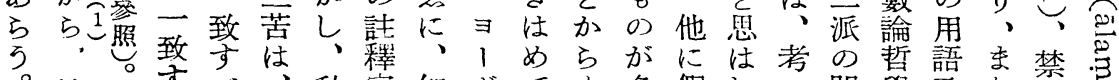

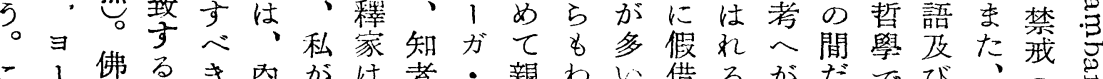

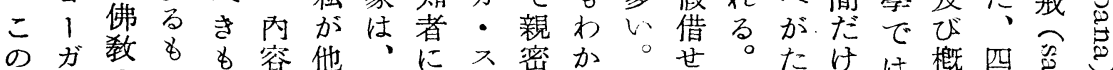

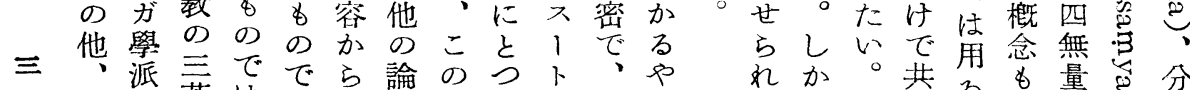

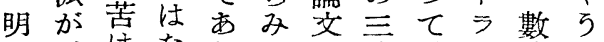

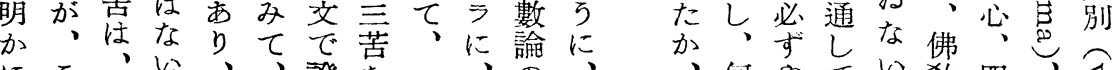

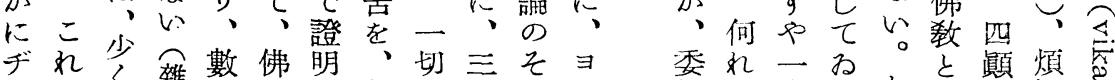

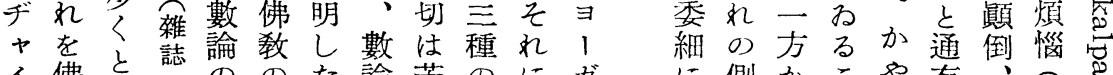

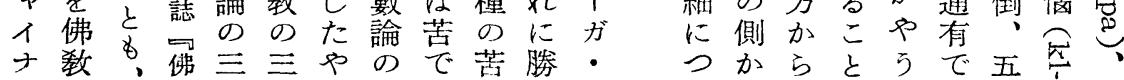


トなのシ はめ

ラたいこュシに前

のたかとヤュ、節

年、らにがヤ不に

代前、屬全の十七

を出こ高面數分る

論のれる的論なす

じ論にばに說ば所

て文つ吕數に吕は

をのいり論吟り、

ら中てでの味で私

れではな形をなが

る、、く而加く他

がヤ他、上へ、で

、コ 日こ學ると論

そ、を〉に必の究

の ビ 期 で・依 要 趣し

手教せ之存が意た

續授ねれするを事

にはばにるる徹 項

於、な立の。底の

て ヨら入はしす概

、1なる、方要

やガいい殆しにで

は・文它、はあ

りス香自バ、る

私 18 明 1 バた
明 シるの辟せ使ら号の でュ・以で數がら用、こ教

あヤそ上あ論、れし自の義

るとこはる說バたた派やを鬲り とをで、。に、の。のう依が 二見一、私 る體\&が とさあし義りし が視し經づヤつてをヨた

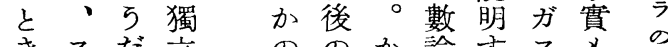

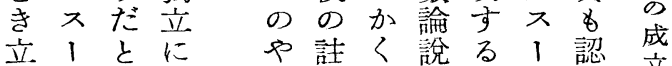

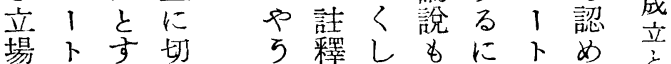
はラれ離に家て亦有ラら佛 そは代しを、、效はれ、教 修の、て 解しそ同な、学充

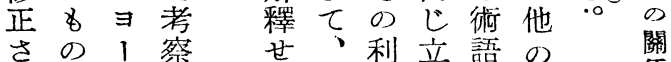

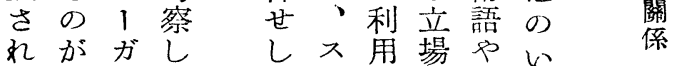
ね、・た文め觀乃金

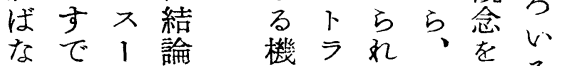
なで な數 ラ梗竞體數しりりな い論と概與を論くい學 のバで へ、的利れ派 解 1あた宛思用てか

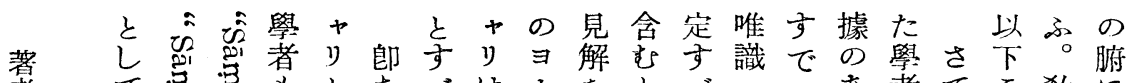

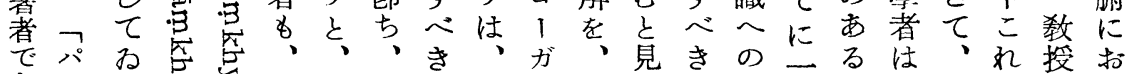
あ

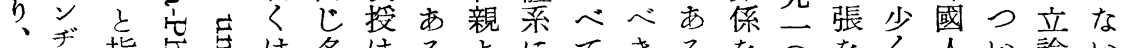

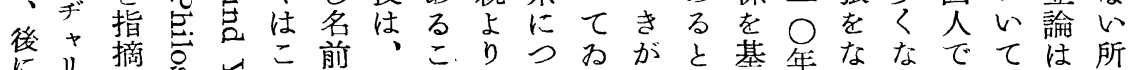

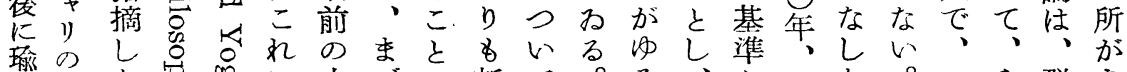

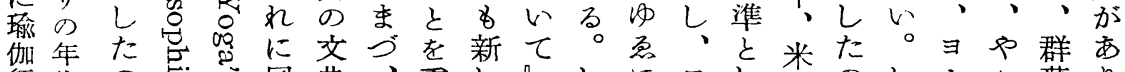

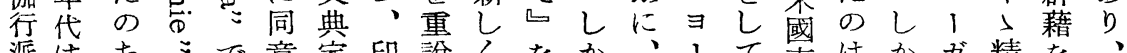
派はちこで意家印說く、を加、1て東はか力精を、

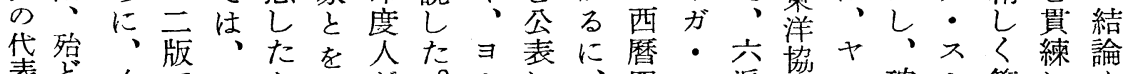

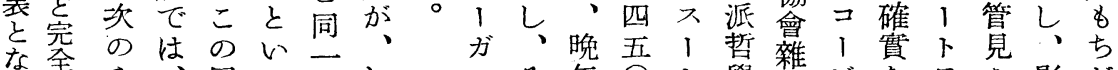
れなや、同ふ心し年

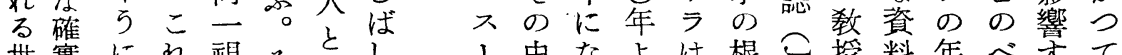

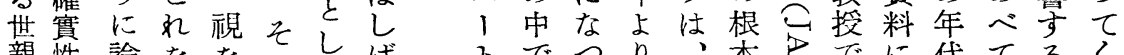

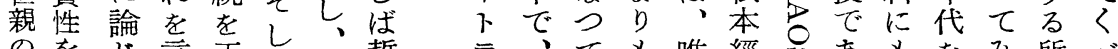
のをし言正て 年以て語當て、學は再、新識典りると漠よもき

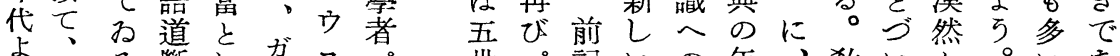

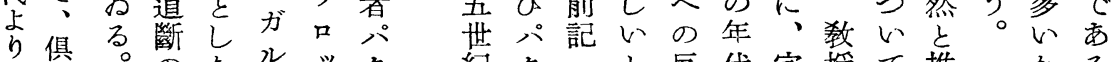

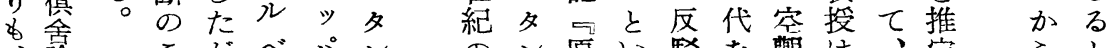
打の 論至がべパン 


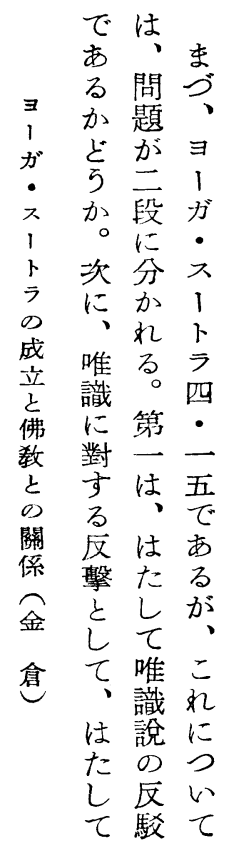

にのの三毛後

分吕根世吾に措こ

紀よ取るとつで過た人四そ に方报加陚の叙去中の・文 てなは說唯定れ指もふらぬ主述のう觀一定 こい、識しで定新際耴要し實に念五む

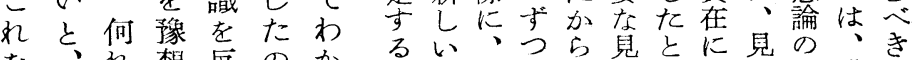
を、れ想反のか こと行とで解注つ齐敉唯で

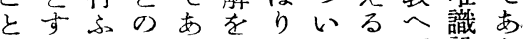
考私多㢦はる 察に不るし、や がれでちる化てかが說ら でばあに。わ知の施正をう

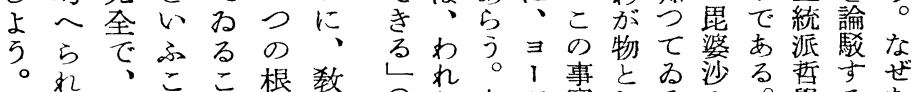

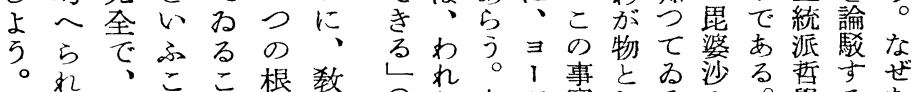

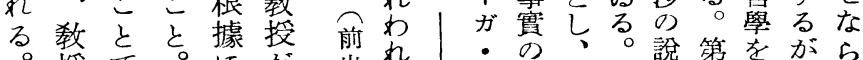

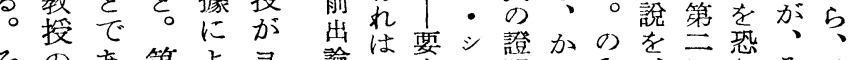

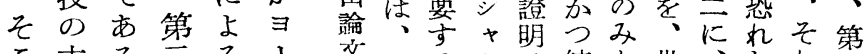
こ主る云る、交ョるたは統な世思れれ第

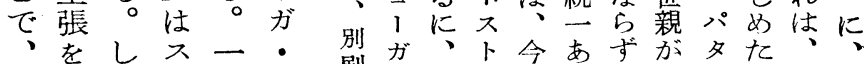

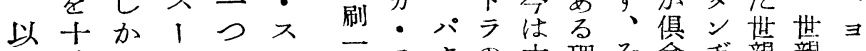
下分るトは1 、スタの表理そ舎ヂ親親、

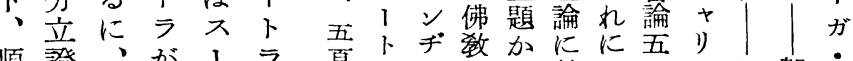

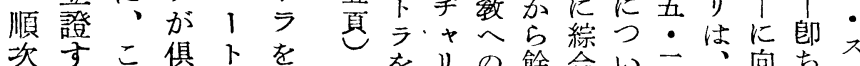

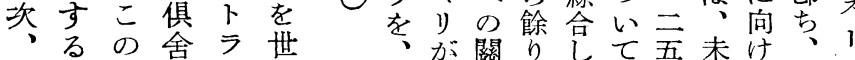
一だ論四親. 五世係離上の以來らそ上 及個の・以親をれう三下とれのテ

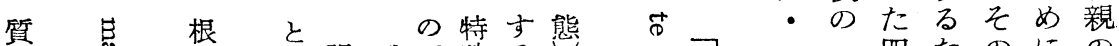

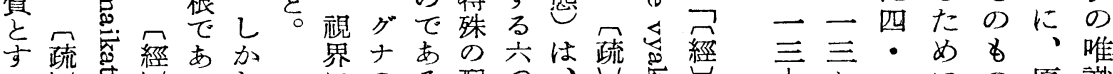

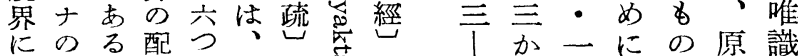

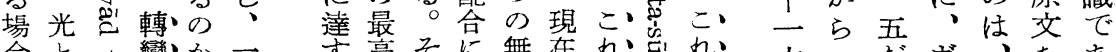

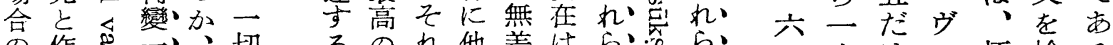

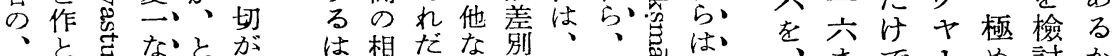

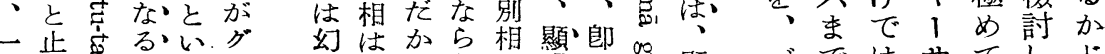

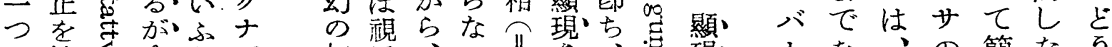

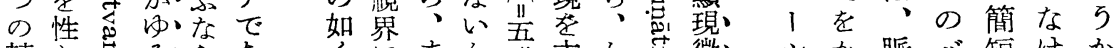

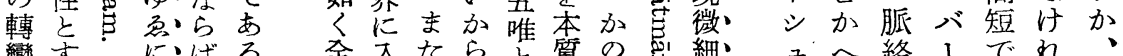

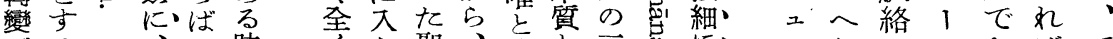

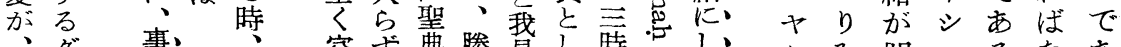

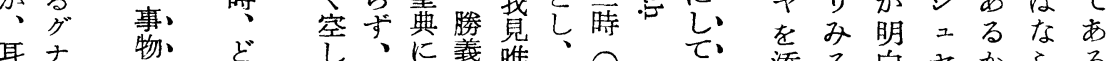

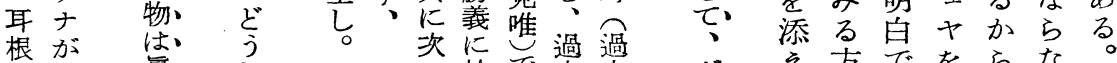

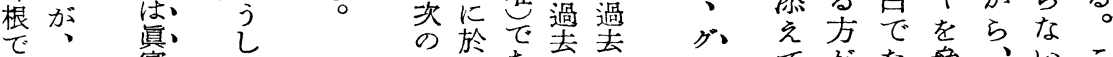

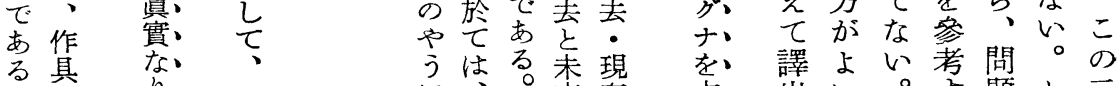

五 る其㔔 一

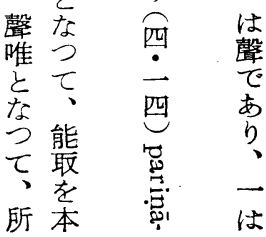
に、こ來在 敎グ、こは离 战圭微・來 兑檻、細の て質り齐法 る。す暂至 本、出い。守題と二

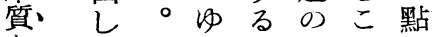
とてょ总必所乃を みつに要在で明 よて、がを、か う之市明不に 以のるか1す 下前。にトる 


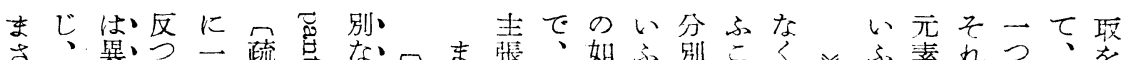

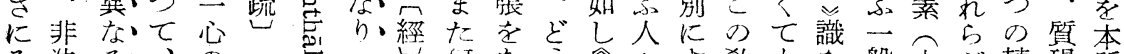

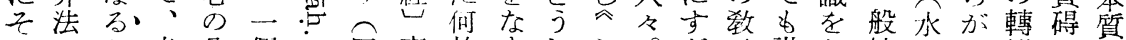

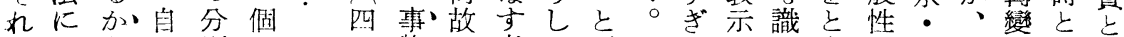
加上ら、6 別の $5 つ$ 安方事 癡て 事立る物 の、事守所以 知ま怙るで、 がさ同所多 あにじでな心 りそく市くの 正か家ま緣 鼠号、なた能 に苦法ぜ多と よ知にな心し てがよ分共 ま支て事別邀 さ的心るる 芯無に会所る そ明樂じず。 かよ知にななれ

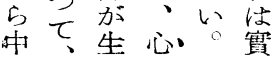

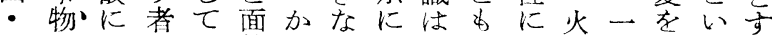
一はこた、前〉いよ存な低・つ方ふる 五阔如り率にる。つ在はつ風のれ共場 しじはえ物篟人夢てすなて・轉ば通合

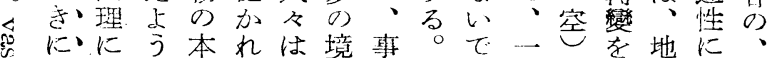

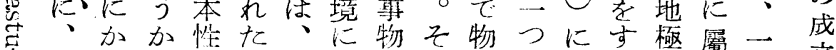
心 心な。瓜こ等のれは於れ微すつ立

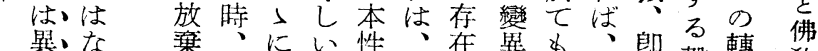

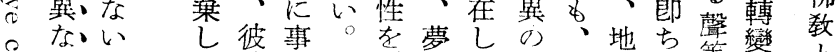
亲るかか、等物勝否等な開之唯等篮

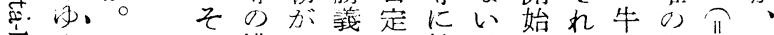

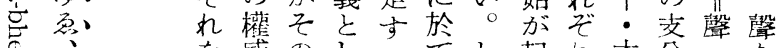

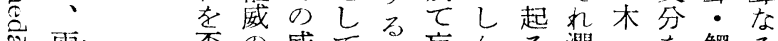

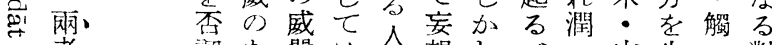

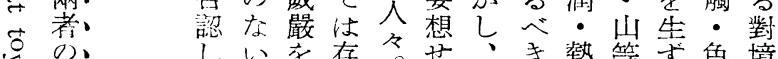

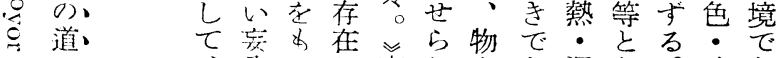

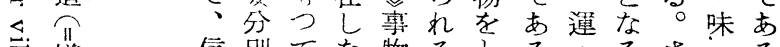
之 關 係 莺㧼

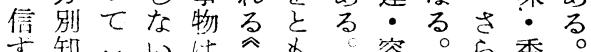

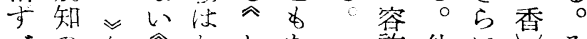

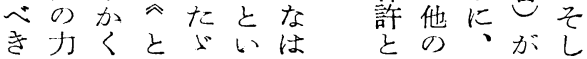

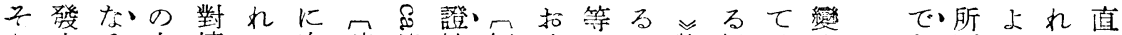

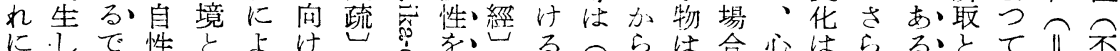

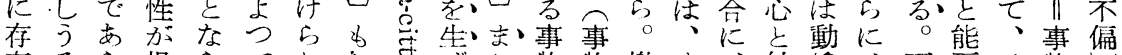

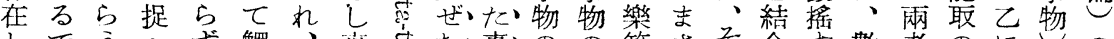

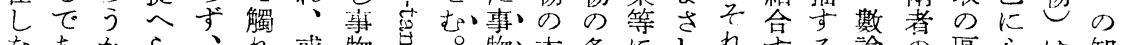

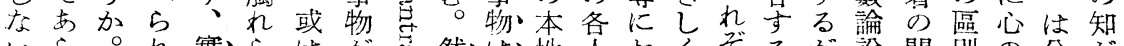
いら○れ實らはが祭は性人打くぞるが說間別の分が こうさな證れ抑一号る-・をのけ知れ。ゆでにで染別あ

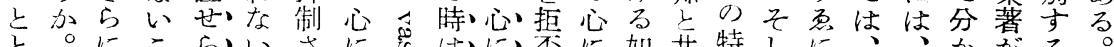

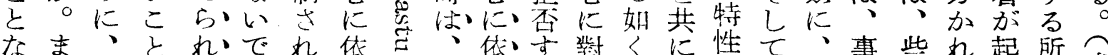

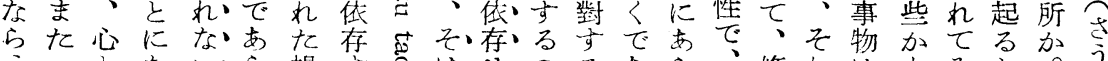

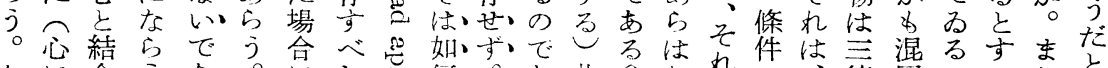

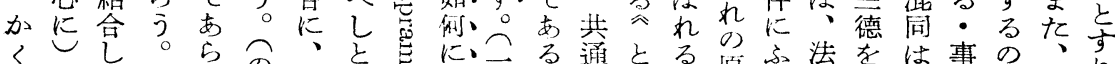

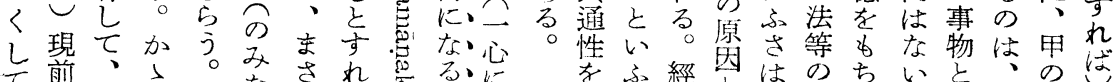

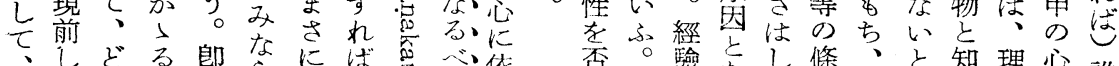

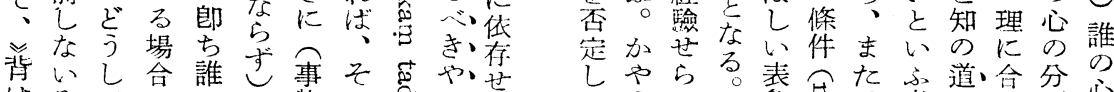

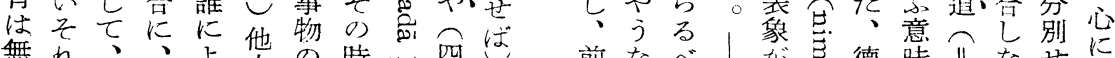

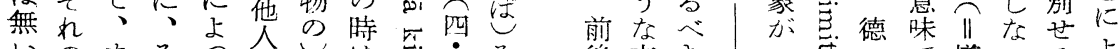

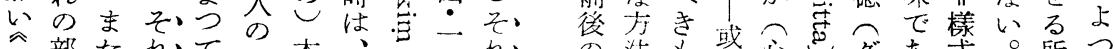

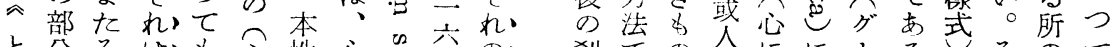

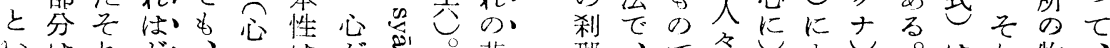

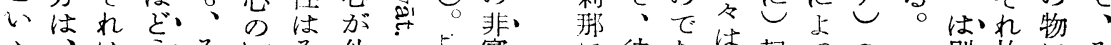

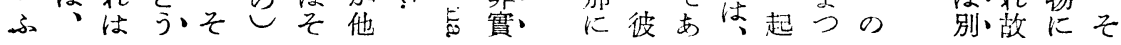




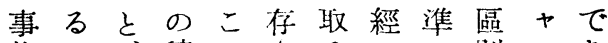

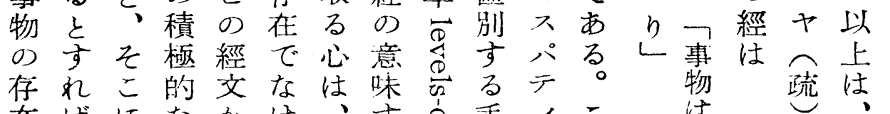

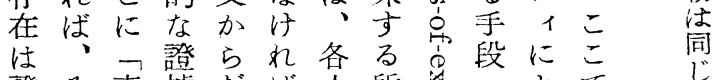

證々事據だば人所忩・文で

明の物は渻なには、

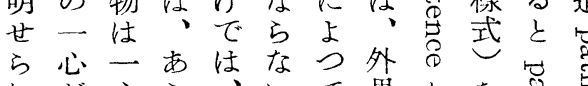

犯心らら、いて界々を焉

な事には唯、異の英意导の

心物依风識とな事譯味.罗語

こに存ながいる物しすすが

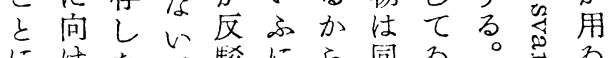

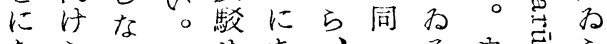

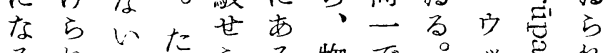

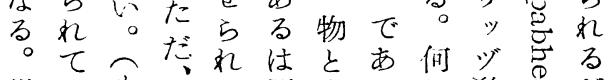

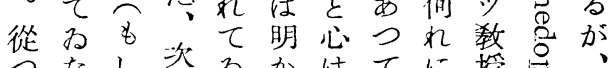

ななし

て事場心經る た

次わ加はてに授焉

物合に文心從つ之的存へは

はに依を学つたれ、在自ヷ

無は存み何て別をこの性!

当子る等、の受の水をチ

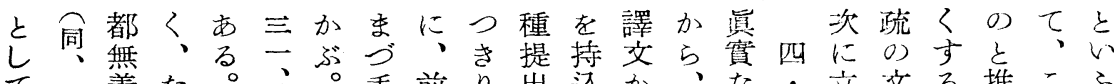

0) 四

己゙

全 -

文 一

の

心 翻 か

は異䛨ら

な あ六

る る ま

总之o

兩 万不

者

道

でト

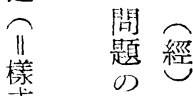

式

住

別

四と

・ バ

-. 1

$7 i$ シ

あるでな

る

こ ヘ:

のて 腹

兩 0 占

者人捕

のに捉

結共せ

合邀的

かでれ

らあな

るい

領 ○て

納まあ

節心

万 को

人獨か

プ立る゙が

ル、ゆ

シ各忽

尒

の存物

享在 は

受し獨

がて立 て三義た。手前り出込汃、な立文る推こる

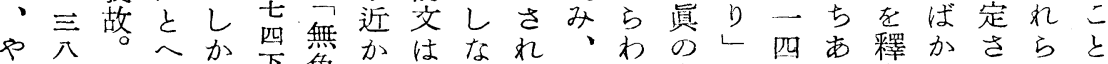

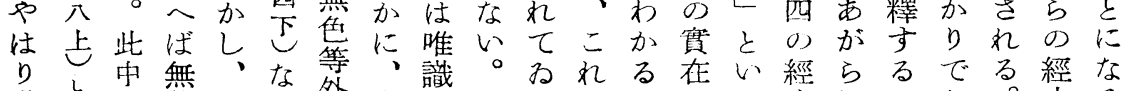

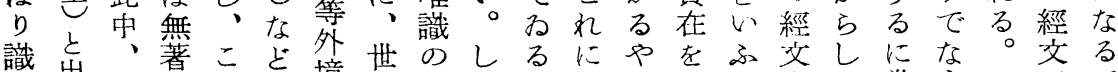

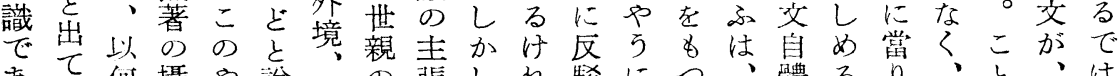
あて 狮攝 や 說 唯

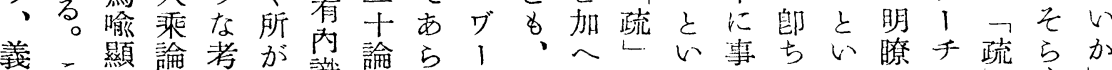

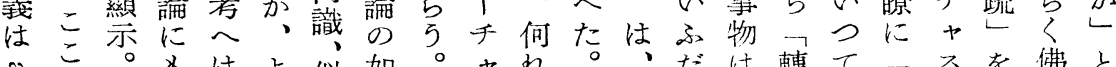

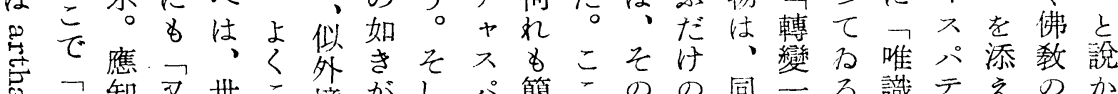

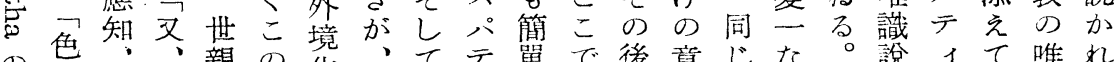

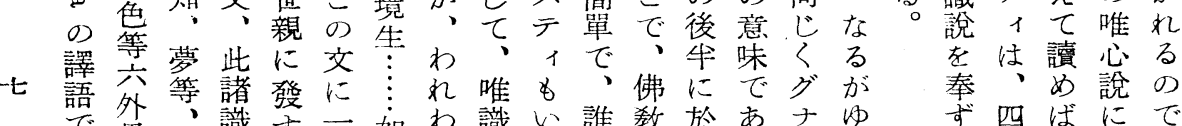

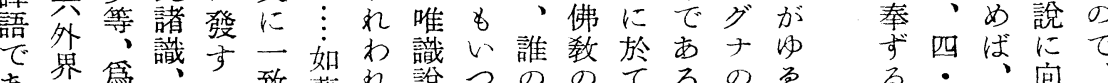

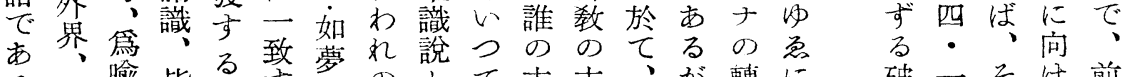

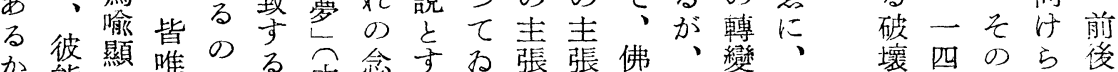

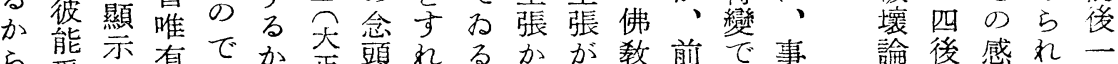
ら態示有でか正頭れるかが教前で事論後感れ自れ

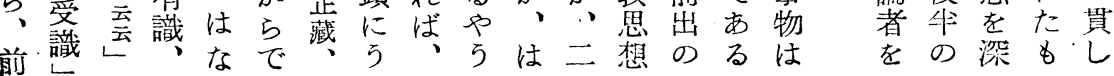




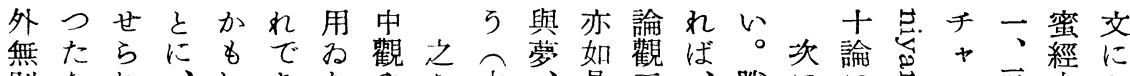

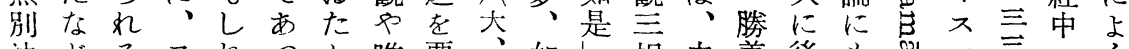

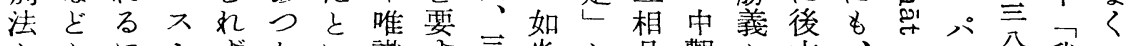

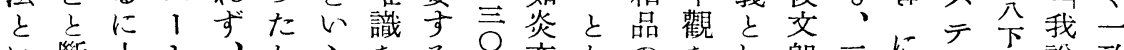

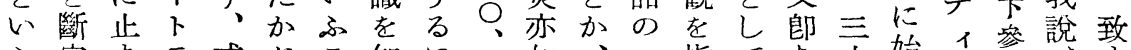

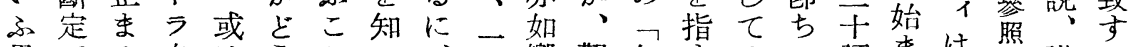

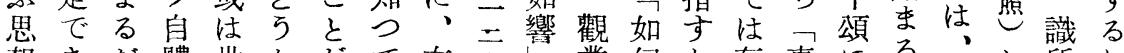
想きた體世かかて右上党業幻と存事にるると所わ はる壮情は親は、る 、痕で、以て如三如の如へしは發偈識る䋨で

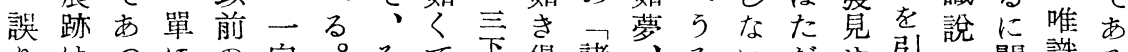

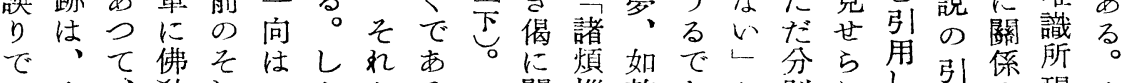

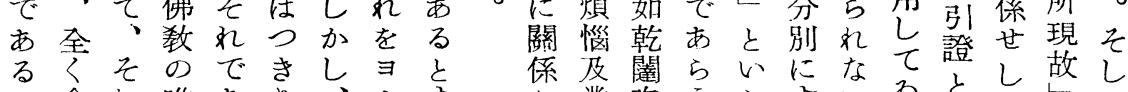

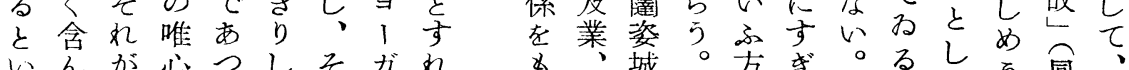

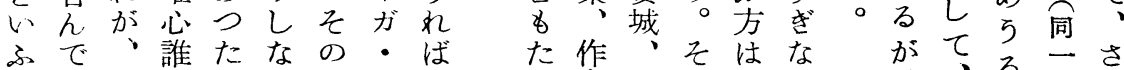
だる世をかい唯ス、者所し、、い、、る゙六ら

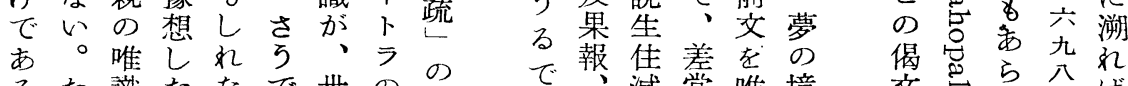
るた識たなで世旗とい作

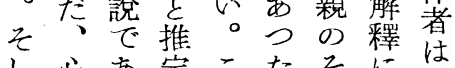
で報住差を蓇當唯境 8 皆、識に あ如其、と等 ら幻相中娄 ᄂ 蓠导ら行 交莺 5中ば は怘 ○゙ 同 解 し心あ定こたそには

三w授が

-てては、ヤ 一四 る こ俱 三論るの舍 に師。點論 ビ 揭のそをの教 计異の、三授 る說要前世 が 所方點出 の 第 と、出を論說二 ๖ る 别豫 根 くると刷 想據 一 が・ - L 致 !俱 の て し して舍四わた てれ論一るの わが卷頁とは るョ三以 と 10 下 しガににこ

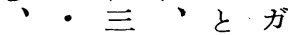
一バ世くで・

そ1のはあ ス にシ別しる、 つュにく。 以ヤつ諭呚 ラ
なるこれれたへ場か䟽從て とばて ぬゆを謂佛、W晎、說來る地か 总世れ教そ。な前を、の悉經〉 に親の、をれつ郎そョは知にる 、說な、はコてでの、、有つ思

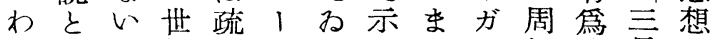
れしこ親のビるしま亡知法界は わたと說說敎。た經不の、虛、 れのはと授ゆやの!事虚妄佛 はは、妄々は急亏意今實傜、教 、、す斷の、ににとだ不但で 次第でしま四、、と關あ真是は に二にたま。こ兩る烈、る實一 第の明た經一の者の元の心す 二根かめの五やはがて 犬無作で の據とで說のう年り經”一、に 根となあと經な代一經九堅十古 據のつつし を見 8 般 疏五固三く を連たた、方作の疏吾相緣か 八 檢連。し親は者傾至吾し分ら 討閵但け加說、向體、な、存 しにしれ。正ち㢳體五亡是し な於、古疏区確加あ吾至、 けて教8に駁とひるなな公說依た

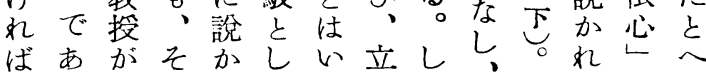




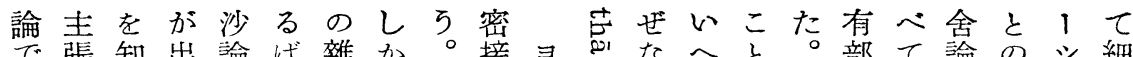
で張知出論ば雜か。接 $ヨ$ ぬなっと。部て論のシ細 子はりて七か阿しこな、がら、はそかのの殆ュか あ、か子七り昆なれ關ガ說、借、こら理報とヤに り成つるっで菬がは係・か三用差か發性告逐に對 万立利。犬な忍らすがバれ・は當ら展的を語お照 るた用しこく論、であ1て二すり盯しな知的けし かなして去にこにるシね㤝でた種た疑りなるて らいたみ夺夻、の、こュるににた轉思ひ、一轉示

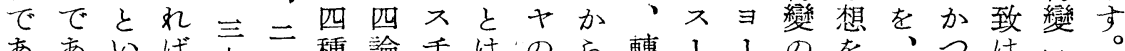

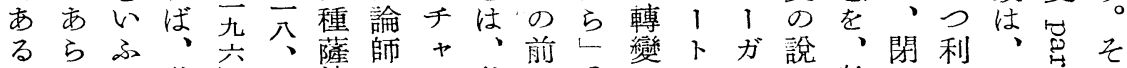

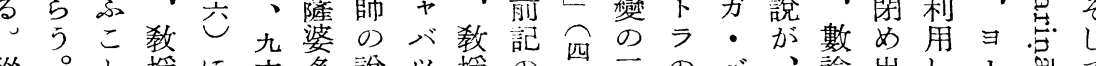

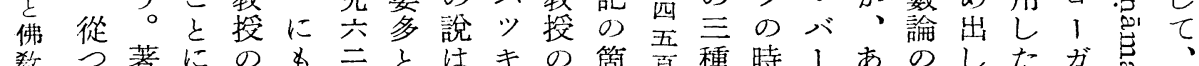

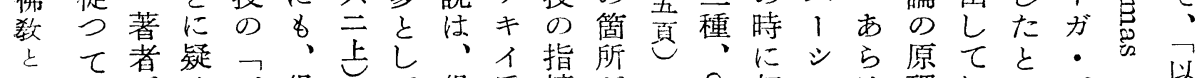

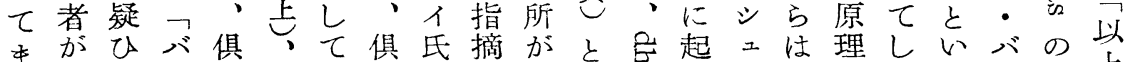

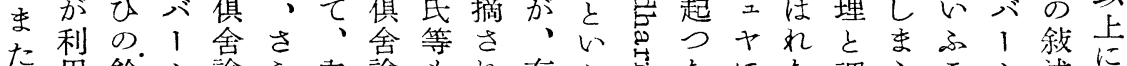
た用餘シ論ら内論方れ仿ふ最たにた調ふこシ述に

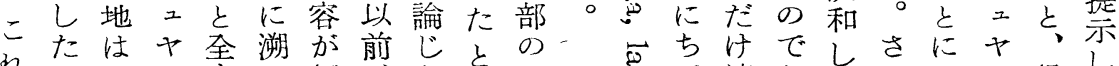
れたはや全溯が前じと紹た をは心著同て算疾所任論 理大し者一、さくでり師 由毘と兮の大れにあでの と婆心俱記毘て法るあ說 七沙ふ舍事婆わ救。弓至

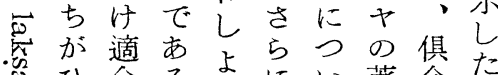

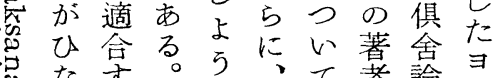

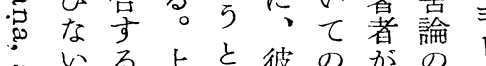

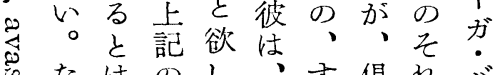
曾なはのしはす俱れぶ

假た虽識で限く有てべ材確はでがな1 定他りをあ年は部まみた料な如あこたト以授、 しのを心る代しのづょ佛を結何るのめラ上のヨ $\tau$ 資つ得。をく四〉う教持論に。論、の、論 1 よ料かてバ示紹見三。とちを考し文證成ヤ證ガ

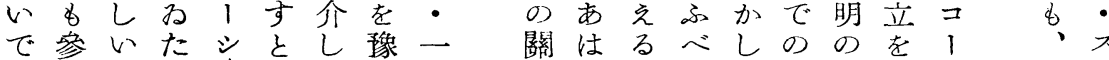
あ考。と之心て想三係せにきな心゙力五ビ根、 らししいヤへねすの加ていかほをを教據卜 うてかふるよるる經ら孙甚が、う紀授をラ

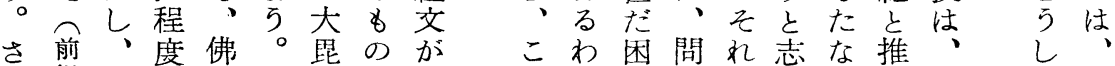

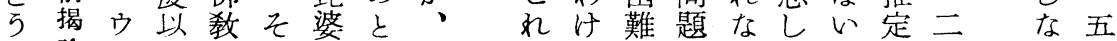
す諭ッ上とし沙すャにでなとらたこ亦種な 世 れ、交少にのて諭れコつは問しば目とるのこ紀 ば空教、關、はば、いな題て、的をけ根をとで 、貝授精係そ、、ビててで殘ヨは明犯據にな

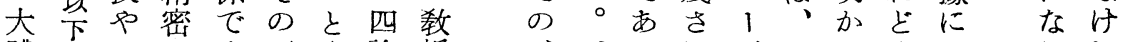

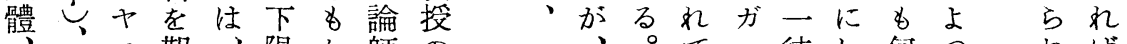

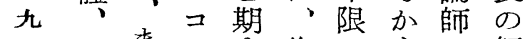
二まり等作はく解 世づビる者、ス說し 紀吾㸚こ㤎バ!をた

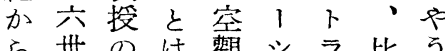
ら世のは雚シラ比 四紀あ、と二の較に 世と壮差唯ヤ上的

二小待し何己权ば

のし私わ不達たれていばな

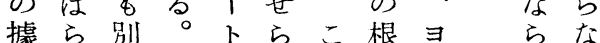
點くにこラれれ據、は市

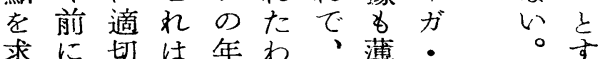

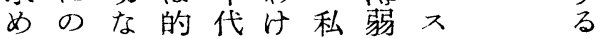




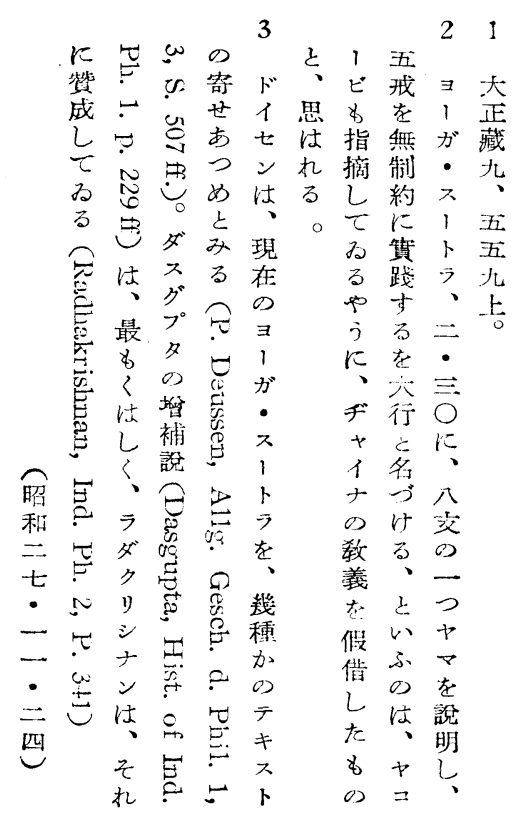

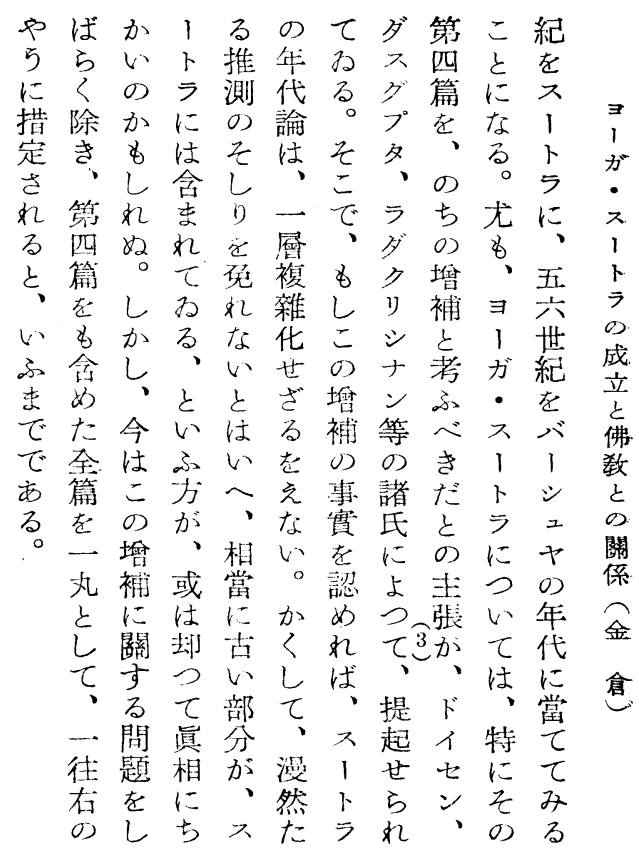

\section{新刊記念論文集內容紹介 I}

\section{Beiträe zur indischen \\ Philologie und Altertumskunde \\ Walther Schubring}

Zum 70. Geburtstag dargebracht von der deutschen Indologie

psu (Thieme), Die Zusammensetzung bei den Infinitiven und Gerundien im Rigveda (Durr), Die angebliche Wurzel bhres (K. Hoffmann), Vedische Skizzen (Lomme1), Der Aśvamedha und der Puruşamedha (Kirfe1), Nīrājanā (Losch), Neues von alten Jaina-Bibliotheken (Alsdorf), Jaina-Versionen der Sodāsa-Sage (Hamm), Die Polemik der Buddhisten und Brahmanen gegen die Jainas (Glasenapp), Vergleichende Analyse des Catuṣpariṣatsūtra (Waldschmidt), Das Zauberbad der Gött́in Sarasvatī (Nobe1), Literarhistorische Bemerkungen zur Sekoddeśațīkā des Nadapāda (H. Hoffman), Amalavijnānam und Ālayavijnānam. Fin Beitrag zur Frkenntnislehre des Buddhismus (Frawwallner), Jayantabhatța und Vācaspatimiśra, ihre Zeit und ihre Bedeutung für die Chronologie des Vedānta (Hacker), Die Lehre vom Handeln in der Bhagavadgitā (Ruben), Metrica (Weller), Ein nicht identifiziertes Gandhāra-Relief (Hansen), Ein indisches Soldatenlied aus dem letzten Kriege (Rau), Indische Seitenstücke zu zwei europäischen Anekdoten (Tavadia),

(Alt- und Neu-Indische Studien, Bd. 7, herausgegeben vom Seminar für Ku1tur und Geschichte Indiens an der Universität Hamburg.)

(Gram, de Gruyter \& Co., Hamburg 1951. S.217) 